\title{
Medical Error - Should it be a Criminal Offence?
}

\author{
MIHA ŠEPEC
}

\begin{abstract}
Medicine is a risky profession where medical professionals have a duty to do anything in their power to help their patients. However, what if a doctor makes a grievous mistake that leads to the death but could have been avoided? Are moral responsibility and apology to patients' family enough? Should we impose sanctions (civil or criminal) on the doctor who negligently caused the patients' death? To answer this questions, we present arguments against criminalisation of medical error, where the strongest arguments are uncertainty of medical standards, counterproductive criminalisation seen in defensive medicine, using criminal law as the last resort, and the argument of doctor's immunity. On the other hand, arguments for criminalisation are obvious negligent treatment with serious consequences, general prevention of future negligent conduct, sanitation of a medical system gone wrong, and the argument of privileged criminal offence. Our conclusion is that criminal law repression of medical malpractice or medical error is justified, however only in the most obvious cases of undisputed negligence or carelessness of a doctor, where his inappropriate conduct has led to a serious deterioration of health of a patient, which could have easily been avoided, if a doctor respected the practice and rules of medical science and profession.
\end{abstract}

Keywords: $\cdot$ medical error $\cdot$ criminal law $\cdot$ criminal offence $\cdot$ medical malpractice $\bullet$ doctor $\bullet$ medical professional $\bullet$ negligent treatment $\bullet$

CORRESPONDENCE AdDREss: Miha Šepec, Ph.D., Assistant professor, University of Maribor, Faculty of Criminal Justice and Security, Kotnikova 8, 1000 Ljubljana, Slovenia, email: miha.sepec@um.si.

DOI https://doi.org/10.18690/2463-7955.11.1.47-66.(2018)

ISSN 2463-7955

(C) 2018 University of Maribor Press

Available at http://journals.um.si/ 
Medicine is one of the most noble and respected professions in society. Society holds doctors in high regard because they consider them members of a learned profession who act as treasured advisors, who helps keep them in good health, who restore ill patients to good health, and who save lives and prevent premature and unnecessary deaths. However, at the same time, medicine is a high-risk profession, fraught with dangers for those that practice it. This is especially the case for doctors that practice in the often high pressure setting of medical emergency services, where a momentary lapse of good professional judgment, for example in diagnosis or treatment of a patient can lead to serious adverse consequences to the patient and sometimes even death. A rough estimate is that in the United Kingdom two percent of patients admitted to acute care hospitals suffer severe harm from healthcare errors (Merry, 2009). Given that medicine deals with one of the most legally secured human rights - right to life - it is undisputed that legal regulation of the medical practice is not only necessary but crucial. In addition, it cannot be seriously disputed that legal regulation of medical conduct which leads to the deterioration of a patient's health, or even to death in cases where this could have been avoided by more careful or professionally adequate treatment, is necessary. Therefore, the question arises as to how the law should regulate and sanction medical errors. In the United States, aggrieved patients that sustain injuries and damages due to doctor error have legal recourse under civil tort law, which allows the patient (the plaintiff) to initiate a lawsuit in court against the doctor and/or the hospital (the defendants) where the negligent treatment was provided, in order to recover monetary damages (Flis, 2016, see also Sonny Bal, 2009). In European countries with the continental legal system and in Japan, criminal law prosecution is also common for healthcare providers that provide professionally poor medical treatment, and which caused deterioration of a patient's health, or which leads to the patient's death, and which could have been avoided if the medical professional had not been negligent or careless in the performance of the treatment.

European countries often incriminate professional errors of doctors in the context of general crimes against the body and life - that is, wounding or causing grievous bodily harm, or causing the death of a person due to negligence - involuntary manslaughter.

In this regard Slovenia is quite unique ${ }^{1}$ since the Slovenian Criminal Code $(2008)^{2}$ contains a special offence of negligent treatment in the Article 179. Under this Article, a medical professional that violates the practices and rules of the medical science and profession, and whose conduct negligently causes a significant deterioration in health of a patient can be sentenced to imprisonment up to three years. Paragraph 3 of Article 179 stipulates that if the patient dies, the sanction includes imprisonment from one to eight years. The offence is classified in Chapter 20 of Crimes Against Human Health, where the central protected right is public health and public confidence in the health system. 
In this paper, we explore whether criminalizing physician negligence in this fashion, and exposing medical professionals, as a special risk group, to criminal liability by implementing a special criminal offence that only they can commit (delicta propria), is appropriate and necessary, from both a legal and public policy standpoint. The two fundamental questions addressed in this paper are therefore, first, should criminal law criminalise medical error committed stemming from mere negligence, and, second, whether modern criminal law requires a specific incrimination of medical error - i.e. negligent treatment in medicine.

\section{$2 \quad$ Medical error - definition and dilemmas}

\subsection{Medical error}

First, we must define how legal scholars define medical error, medical malpractice, negligent treatment, medical mistake, doctor's error, doctor's fault or doctor's mistake. All of these phrases are used more or less synonymously. However, it is more appropriate to speak of medical error, medical mistake or medical malpractice, since the latter terms are not limited to doctors but also include negligent treatment rendered by other medical professionals (anaesthetists, medical nurses and other health professionals that treat or help treating the patients). ${ }^{3}$ Doctors and hospitals are expected to provide medical treatment employing all of the knowledge and skill at their disposal. Doctors owe certain duties to their patients and a breach of these duties triggers a cause of action for negligence against the doctor (Pandit \& Pandit, 2009).

In the IOM report "To Err Is Human: Building a Safer Health System", clinical error was defined as failure of a planned action to be completed as intended or the use of a wrong plan to achieve an aim (Kohn, Corrigan \& Donaldson, 2000). ${ }^{4}$

Legal definitions of medical error began in 1869 when medical expert Rudolf Virchow defined medical error as an error that occurs in a deviation from the generally accepted rules of medical profession because of insufficient care (Matz, 1869, in: Kaufman, 1989).

Today, medical malpractice is defined as an act or omission by a physician or medical expert during treatment of a patient that deviates from accepted norms of practice in the medical community and causes injury to the patient (Sonny Bal, 2009). Grunsven (1997) argues that only an extreme deviation from generally accepted standards of practice should constitute gross negligent medical care.

It is undeniable that in criminal law, the first element that must be considered when determining whether a doctor's negligence or medical error constitutes a chargeable offence is to determine whether there was a breach of the medical profession's standards (Korošec, 2016). In other words, we must establish if the medical 
professional carried out the medical care in accordance with accepted standards in the medical community, and if not, what alternative medical care would have been appropriate in the given situation. There is no question that these questions require medical expert testimony, since judges, juries and even legal experts lack the necessary medical knowledge and expertise to answer these questions. For example, the views of legal experts can differ from those of medical experts. What medical experts define as wrong, unacceptable, criminal medical care, or as constituting a mistake, an error, negligence, or lapse in treatment or the like is practically irrelevant to a criminal lawyer. To the contrary, the only important fact that must be established is whether the medical professional's treatment in fact deviated from the accepted standards of the medical community (Korošec, 2016). These standards are defined by medical expertise and science on both national and international levels. It is therefore abundantly clear that if the medical profession itself cannot answer the question whether a defined instance of medical care was performed in accordance with accepted medical standards, or if the medical profession cannot even provide an answer as to how a medical professional should act in a defined instance (e.g. a new yet undiscovered disease where there is no medical knowledge on how to treat it), there can be no criminal responsibility on the part of a medical professional that would demand criminal prosecution. In other words, no person, whether a professional or otherwise, can be convicted of a crime for engaging in conduct that has not been well defined as being criminal. This principle is as selfevident as requiring no citation of authority. Therefore, a medical expert's final opinion, when asked what the appropriate standard of care was under the circumstances, of "I do not know," reflects the kind of uncertainty and vagueness that must exonerate the doctor from wrongdoing and must therefore always lead to a judgment that no criminal offence was committed, since the basic premise of a criminal medical mistake or negligent treatment is missing - a violation of a wellaccepted medical norm, i.e, standard of care (Korošec, 2016).

It is evident that not every deterioration in a patient's health or even death during treatment is the direct result of a medical error (i.e., breach of the standard of care) as sometimes both are a natural consequence of the patient's condition and simply cannot be avoided, even with the best medical care. A medical accident, for example, is defined as an unwanted, unexpected, random event that happens with all due care of a doctor who took all the necessary precautions to reduce the risk of a potential accident (Flis, 1994). Similarly, medical complications quite frequently occur during the course of medical treatment that is performed professionally and with all due care. Medical complications are expected, but occur randomly and cannot be predicted with any certainty (Flis, 1994). Complications and accidents are normal during complex procedures (Grunsven, 1997) and cannot be attributed to doctor's mistakes or errors, especially if the doctor has taken all the necessary and needed precautions to avoid them. 


\subsection{Elements of criminal liability}

When discussing medical error as a criminal offence, we must first define the elements of criminal liability that must be met in order to find a medical professional guilty of that offence. First, there must be a legal duty on the part of the doctor to provide care or treatment to the patient. In other words, there must be a professional relationship between the patient and the healthcare provider (Sonny Bal, 2009). There is no professional relationship when a person who is not a medical expert provides emergency help to someone in need of it. There is, nevertheless, a duty of care which arises, which could result in criminal culpability when the emergency treatment provided worsens the health condition of the person in need and the treatment was in fact not that urgent - this depends on the Good Samaritan Law of the country, and whether and how the omission of help is defined as an offence in the Criminal Code. There is also no professional relationship formed in a case where, for example, a heart surgeon who is enjoying a vacation at sea and provides some emergency treatment to a person at the beach who has a heart attack. In such a case, courts would likely conclude that since no doctor-physician relationship was established, the volunteering surgeon owed no duty of reasonable medical care (Sonny Bal, 2009).

The next element is acting in contradiction with the practice and rules of the medical science and profession - i.e. a violation of the medical profession (breach of the standard of care). We have already discussed this element in the previous chapter and will do so again in chapter 3.1 .

Thirdly, there must exist causation between a doctor's treatment that violates the rules of medical profession and a patient's significant deterioration of health. The dominant theory of causation in criminal law is the equivalence theory. The equivalence theory is based on natural cause causation, where the basic concept is the formula sine qua non, which attributes causality to the conduct of the perpetrator only if his conduct is a necessary condition for the prohibited consequence - e.g. if the doctor had not performed the treatment, the patient's health would not have deteriorated. However, we must also take into account other causation theories the theory of adequate causation (Dežman, 2010) and the theory of acting in accordance with regulations. The theory of adequate causation emphasises the value criteria. That is to say, under this theory the doctor's duty of care requires conduct that is normally expected of a doctor in a specific case, while also taking into account the developments that occur in the regular course of events. So for example, there will be no legal causation and therefore no liability when the result that occurs would almost never have happened as the result of a doctor's treatment - e.g. a doctor injects a vaccine that has no reported side effects into a child, but in the particular case the vaccine triggers a severe reaction and deterioration of the child's health, which the doctor could not have foreseen (see also Korošec, 2016). 
The causation theory of acting in accordance with regulations postulates that causation cannot be attributed to a doctor who has violated the medical standards when treating a patient in the case where the consequence of the treatment would have occurred even if the doctor had acted in accordance with medical standards e.g. a negligent doctor does not perform the much needed and urgent examination of a sick patient, but even if he had performed the examination, it would make no difference, since the patient would have died anyway.

The last element required to establish criminal liability is the doctor's negligence. In criminal law, medical error can lead to a criminal culpability only if the doctor has been negligent. If the doctor acts with the intent to kill or injure a patient, this is not considered only a medical error, but a criminal offence of murder, or wounding and causing grievous bodily harm with intent. A medical error, on the other hand, consists of conduct on the part of a doctor, who is not careful enough, who is inattentive, carefree, or acts in any other way that is inconsistent with and falls below the standard of care in the medical profession. To use an example, a doctor fails to order blood analysis on a child, erroneously believing the child's medical problem was nothing to worry about and that there would be no complications, when in fact, the testing would have easily detected a serious infection, which could have been treated without complications by the use of antibiotics. Under this hypothetical, assuming the standard of care required the doctor to order the routine blood testing, the doctor most probably breached the standard of care; the breach was the proximate cause of further injury to the child; and, the doctor was negligent. Negligence is, therefore, conduct that departs from the standards expected of a reasonably prudent person. Using our hypothetical, since the "actor" or "person" in question is a doctor, and hence is a medical professional, we must ask the additional question, would another doctor with the same knowledge have acted as he did. The offence of medical error may be committed by making an error of judgment or an error in the execution of treatment of a kind that a reasonably prudent and skilful doctor would not have made. In the case Adomako - John Assare in 1995 an anaesthetist failed to notice that the tube supplying oxygen to a patient had become detached. According to expert evidence, any competent anaesthetist would have recognized this immediately (Ormerod, 2005). Ormerod (2005) argues that whether the actor is negligent is, therefore, measured by an objective standard, namely, whether the risk of harm would have been obvious to the reasonably prudent and skilful doctor, anaesthetist or other medical professional, as the circumstances require. This is an approach of the Anglo-American criminal law doctrine. Continental criminal law doctrine, on the other hand, emphasizes subjective criteria, which turns on the question of whether the accused had the possibility and was aware of how he should have acted based on his personal experiences and training (Bavcon et al., 2014). Under this standard, a skilful surgeon practicing in the most state of the art hospital should exercise more prudence and care than would be required of an average doctor practicing, for example, in a local or rural clinic. This approach has come under criticism. Pandit \& Pandit (2009), for example, argue that for liability to attach, the manner and 
nature of treatment has to be so deficient that it falls short of the skill and/or standard expected from average medical practitioners and not that of the highly qualified and exceptionally gifted. This approach was also adopted in Anglo-American court practice. In the case of Bolam V. Friern Hospital Management Committee (1957), ${ }^{5}$ the court adopted the Bolam test and argued: "A man need not possess the highest expert skill: It is well established law that it is sufficient if he exercises the ordinary skill of an ordinary competent man exercising that particular art. In the case of a medical man, negligence means failure to act in accordance with the standards of reasonably competent medical men at the time."

Brenner et al. (2012) question the negligence standards in the medical profession. They argue that medical negligence cannot be adjudged simply by examining nonconformity to norms but rather that we should consider two additional concepts before imposing legal liability - justification and excuse. By way of explanation, medical conduct is justified when the benefits of a certain course of conduct outweigh the risks. The public policy argument in favour of this approach is that the law sanctions the conduct and encourages future conduct under similar circumstances. The notion of excuse, on the other hand, relieves a doctor of legal liability under specific circumstances even though the doctor's conduct was not justified (Brenner et. al., 2012).

An interesting approach in the continental criminal law doctrine was taken in the Austrian Criminal Code (Strafgesetzbuch, StGB, 2016, paragraph II of Article 88) ${ }^{6}$, which decriminalises bodily harm resulting from negligence when committed in the exercise of a lawfully regulated health profession, assuming there was no gross negligence. Gross negligence is not a criminal law standard but a standard of the civil law, and according to the proposed definition, occurs when someone acts in an unusual and conspicuously negligent manner, whereby the occurrence of a state of affairs corresponding to the legal facts was almost certainly foreseeable (Halmich, 2016).

\section{$3 \quad$ Arguments against criminalisation of medical error}

Should medical error therefore be a criminal offence, and if so, under what circumstances? We will first present the principal arguments against criminalisation of medical error.

\subsection{Uncertainty of medical standards}

Unfortunately (or fortunately, depending on your point of view) medicine often lacks the certainty associated with other sciences such as mathematics and therefore is not considered to be a definitive science, since it suffers from some of the same limitations as exist in the law - for example, the vagrancies and unpredictability of people, who because of their diversity in their social mores rarely adopt to the same standards. Kennerly (2013) states that "Any physician who is $99.99 \%$ certain that 
patient did not suffer a heart attack is unfit to practice medicine. A patient history and physical examination will never give any physician enough information to be " $99.99 \%$ " or $98.78 \%$ or $73.64 \%$ or $22.13 \%$ or $00.01 \%$ certain of anything." In 1959 , Helmer and Reshner argued that, "In medicine, exact explanation of causes of diseases, concise diagnosis and absolute predictability of outcome of treatment are difficult, if not impossible!" (Halmer \& Reshner, 1959) and even earlier, in 1952, King declared, "Medicine will not achieve the status of science until the basic laws of health and disease have been disclosed," (King, 1952).

It is undeniable that in 2018 medicine is considered one of the leading sciences in the world. However, despite its many advancements this does not mean that medicine will always provide clear and unambiguous answers on how a certain patient in a certain situation should be treated. Far from being black and white, medical practitioners often have to make difficult decisions that fall within the grey area, where there are not always $100 \%$ correct answers and solutions. For example, while doctors can often make a definitive diagnosis of a patient's condition, in many other cases they are left instead with making differential diagnoses, due to uncertainties and lack of clear evidence that speak against a conclusive diagnosis. We have already explained that a basic element of imposing criminalisation of a medical error is the prerequisite of proving the doctor's actions or inactions violated the practice and rules of the medical science. It cannot be disputed that the goal of a trial in a medical negligence case is to reach a fair and just decision on whether the patient's injuries should be attributed to the doctor. At the most fundamental level, to achieve fairness and satisfy constitutional notions of due process of law in a medical negligence trial, clear and well-defined criteria for determining medically negligent conduct are essential (Brenner et. al., 2012). However, Brenner et. al. (2012) argue that any standard of care that is based solely on conformance with the practice and rules of the medical science is a faulty and distorted measure of medical negligence, since it is necessarily based on the flawed deductive reasoning of compliance with the professional conduct or norms of the majority of practitioners that is presumed to be (but in fact may not be) reasonable, diligent and prudent. First of all, there is no guarantee that the majority is reasonable, diligent and prudent. Secondly, physicians who deviate from customary norms may not necessarily be acting in ways that are in fact unreasonable or reckless. "In fact medical progress has often come from the practices of nonconforming doctors whose innovations derived from alternative ideas about the norms of medical practice" (Brenner et. al., 2012). In Helling $v$ Carey $(1974)^{7}$, the court found the doctor negligent for not recognizing a glaucoma, although according to the accepted standards of care, routine screening for glaucoma was not performed on patients younger than 40 years old. Helling was under 40. The doctor did therefore comply with the standard norms in his profession. The legal issue before the court was whether compliance with the professional standards of a specialty satisfied the appropriate duty of care. The specific ruling in the case was that professionals whose actions conform to the standards of their given specialty may, nevertheless, commit malpractice if such conduct is not reasonably prudent. In support of this ruling, the court reasoned, 
"What is usually done may be evidence of what ought to be done, but what ought to be done is fixed by a standard of reasonable prudence, whether it is usually complied with or not." In other words, in Helling the court thus demanded a higher standard than the professional standard of care.

Medical standards can also differ in certain cultures or countries with different medical systems (countries with compulsory health insurance or countries without it). It should be undisputed that when there are more widely accepted standards of care the doctor should not be prosecuted for adopting one of them - although it was not the best option for the patient. Thus meaning that when there are more than one treatment options and all are within the appropriate standard of care, and the doctor chooses one of them, and gets a poor outcome, the doctor should not be held liable for not choosing the other options.

In the case of Bolam V. Friern Hospital Management Committee (1957) ${ }^{8}$, for example, the court declared, "There may be one or more perfectly proper standards, and if he confirms with one of these proper standards, then he is not negligent."

Legal scholars often argue about the meaning of certain legal constructs or standards. In criminal law, for example, we have as many definitions of guilt as we have scholars. To answer this dilemma Ronald Dworkin, a famous legal scholar, presented a metaphor of Judge Hercules, a hypothetical ideal judge, immensely wise and with full knowledge of legal sources. In American tort law, by analogy, expert Dean Prosser, who authored the Handbook on the Law of Torts, in trying to explain to law students the concept of negligence, refers to the (defendant) actor as being the "reasonably prudent person" all knowing, ever careful, and always acting with just the degree of care and caution necessary under the particular circumstances to avoid liability (Prosser, 1978). Acting on the premise that the law is a seamless web, Judge Hercules is required to construct the theory that best fits and justifies the law as a whole (law as integrity) in order to decide any particular case. Dworkin argues that Judge Hercules would always come to the one right answer (Dworkin, 1986). By further analogy, in medicine, the utopian medical practitioner would be Doctor Hippocrates, a brilliant and all-knowing doctor that would always give us one right answer. Medicine however is not practiced in a utopian realm, but rather in the real world, where there is no Judge Hercules and there is no Doctor Hippocrates and where doctors have flaws, and have to deal with shades of gray and everything is not monochrome. Given these realities, how then can we find the correct answer? Why should we penalize a doctor who is not Hippocrates and who might not employ the most optimal treatment, although he is trying his best to heal his patient, and does employ a reasonable and accepted treatment, which nevertheless does not work in the end? If there are no definite and clear standards of care, then the law should not penalize the doctor for providing treatment that is reasonable but leads to suboptimal results. Criminalisation of such behaviour would be unfair. 
On the other hand, we can safely argue that the less complex the disease or the problem, the easier it will be to find the right answer. Errors such as improper transfusion, wrong-limb surgeries, administration of the wrong dosage of medicine, administration of medicine to the wrong patient or at the wrong time, the doctor's lack of hygiene, overlooking simple signs that any sensible doctor would have found, all can be categorized as gross negligence and the defence based on complexity of medicine must necessarily fail. Obvious medical errors fall under the standard of res ipsa loquitur or negligence per se - such cases do not need any special evidence or expert testimony to be established. Instead, negligence is established as a matter of law.

\subsection{Counterproductive criminalisation - defensive medicine}

Ashworth and Horder (2013) present a minimalist approach to criminal law where one of the basic tenets of criminalisation is the principle of not imposing criminal sanctions where doing so would be counterproductive; that is to say, not establishing a criminal offence(s) for certain behaviour where the harms associated with doing so substantially outweigh the social utility of imposing such criminal sanctions. "The argument here is if the criminalisation of certain conduct gives rise to social consequences that are hardly better than the mischief at which the law aims, this militates strongly in favour of decriminalisation" (Ashworth \& Horder, 2013).

In medicine, the greater harm is in the so-called practice of defensive medicine, which can be defined as the modification of clinical practice solely to reduce exposure to legal challenges by patients or the state, rather than direct clinical reasons (Oyebode, 2013). As explained by Heller (2017) practice of defensive medicine in the US has led to massive increase on cost of distributing medical service, and a largely broken medical system. Exposing doctors to criminal responsibility whenever anything goes wrong since they did not fully adapt to the traditional standard procedures of the general community will suppress any kind of progress in medicine. Taking this to the extreme, one could argue that if doctors are never willing to deviate from accepted norms, and never willing to take any risks (i.e., think and act "outside the box") with the patients solely out of fear of legal liability, whether civil or criminal, the logical result could be the stagnation or even the regression of medicine as a profession which in turn is detrimental to the advancement of the profession and therefore a loss to the whole society. Studies have shown that legal sanctions against doctors are correlated with the use of defensive medicine - a survey of Italian general practitioners and specialists found that $37 \%$ of GP and $83 \%$ of specialists had engaged in at least one defensive practice in the previous month (Miller, Samson \& Flynn, 2012). Nonetheless, this argument must not be misused so that the patient would become a "test bunny" at the hands of the doctor, who abuses the consent of the patient and is derelict in the duty to inform the patient about all available medical options - as was the case of Aoto Hospital in Japan, where three young, inexperienced urology surgeons performed "keyhole" laparoscopy on a prostate cancer patient in order to gain experience with 
a high-tech procedure. They neglected to inform the patient of their lack of experience in the procedure; the possibility of serious intra-abdominal bleeding experienced by patients of other, more experienced surgeons; and, the existence of well-established standard alternative treatments (Leflar \& Iwata, 2005).

\subsection{Criminalisation as a last resort}

Related to the previous argument is the further argument that criminalisation should be used as a tool of last resort given its draconian nature. Within the law, there are at least two other major remedial schemes available to regulate medical negligence and error, either or both of which are often preferable to criminalization: civil liability, best exemplified by the laws of tort and contract, and administrative regulation. The minimalist principle of criminal law expressed in the de minimis limitation is, that the criminal law should not be used to punish minor wrongs (Ashworth \& Horder, 2013). Dežman (2010) lists administrative measures that can be taken against a doctor, including warnings, obligatory professional training, and even medical license withdrawal in more extreme cases. He posits whether a personal sense of guilt, professional compromise, negative public opinion and even a loss of a medical license are not severe enough sanctions, and whether it truly is necessary to add to that the threat of criminal law repression.

\subsection{Justification and excuse argument}

Brenner et. al. (2012) present this argument in favour of decriminalisation that is based on the utilitarian rule that in the medical profession the benefits of a certain course of action (even if outside the standard of car or perhaps illegal) outweigh the risks. They argue that medical negligence is not simply nonconformity to existing norms of conduct and that we should consider two additional concepts of legal liability - justification and excuse. The concept of justification means that certain medical conduct may be justified when the benefits of that conduct outweigh the risks. The doctrine of excuse, on the other hand, relives a doctor of legal liability under specific circumstances even though his conduct was not justified (Brenner et. al., 2012). These are well-established concepts of necessity in continental criminal law doctrine (see Roxin, 2003; Jescheck \& Weigend, 1996; Ashworth \& Holder, 2013), where conduct that could have otherwise been classified as criminal, in certain circumstances is either justified or excused - e.g., a non-licensed student of medicine performs an emergency abortion on a woman outside a hospital setting and not in accordance with medical standards. However, the procedure was absolutely necessary to save the lives of both the woman and the baby and there was no time to wait for medical assistance.

We therefore see no reasons to modify the concepts of justification and excuse in criminal law solely for the medical profession, since both concepts are completely applicable for the medical profession. Therefore, this cannot be treated as an 
argument for decriminalisation of medical error, but rather more of an exclusion for situations where medical error will not be regarded as criminal offence.

\subsection{Argument of immunity}

Judges in the rule of law countries enjoy procedural immunity that protects them from legal responsibility when passing judgments in court. In order for a judge to pass the judgment fairly, and without fear of legal reprisal and retribution, he or she must be protected not only against legal action from the people he or she passes judgment on but also from potential sanctions by the state. However, if a judge must be protected in order to judge fairly, can we not say that a doctor should also enjoy some degree of immunity in order to heal patients properly?

The argument is not without merit since the nature of the work of both professions is often quite similar. A negligent judge can destroy a person's life (e.g., sending an innocent person to jail by negligently performance of duties or taking away a person's essential belongings by negligent interpretation and application of the law) and a negligent doctor can cause a person's death or serious damage to the patient's health. However, a judge will enjoy at least a qualified immunity even if a higher court ultimately decides that the judgment was entered erroneously in violation of applicable legal doctrine, while a doctor receives no such protection (except maybe from colleagues who present their testimony as expert witnesses). In the Yugoslavian criminal law doctrine, medicine was regarded as an exception to criminal unlawfulness because of its social benefits to society. In modern criminal law (heavily influenced by German criminal law doctrine), this radical special treatment of medicine has become rare and it seems that it no longer comports with modern notions of a person's dignity, right of self-determination, autonomy and the right to free development of personality (Bavcon et. al, 2014). Furthermore, the procedural immunity afforded to judges is not the absolute or intrinsic right of a judge, but rather a legally afforded privilege that is not intended to protect the judge as an individual, but to the contrary is intended to prevent the possible obstruction of work of the judicial authority by triggering manifestly unfounded criminal proceedings (Constitutional Court of Slovenia, 2012). ${ }^{9}$

\section{$5 \quad$ Arguments for criminalisation of medical error}

\subsection{Obvious negligent treatment with serious consequences}

Situations where doctors neglect basic principles of proper treatment, make apparent mistakes, abuse the patient's right to consent to treatment, and conduct themselves in manners not befitting of their profession cannot be excused. When such self-evident negligent treatment causes serious consequences to a patient's health, there is no real reason why the state should not legally sanction such behaviour - even under criminal law. A doctor who is drunk during a surgery, one who leaves a scalpel in the body of a patient, or one who is not careful as to which 
limb he must operate on and similar cases involving clear negligent or careless acts, cannot be excused and glossed over under the guise of general notions that medicine is good for the society and that doctors should not answer for serious acts of malfeasance because they help people. Carless, amateurish, dilettante doctors, surgeons, medical nurses and other medical professionals, who as a consequence of their negligent acts or omissions which could have easily been avoided, cause serious deterioration of health and even death to their patients, should be expelled from medical profession. A prime example of this is the case of People v. Milos Klvana in $1992 .{ }^{10}$ There, Doctor Klvana was convicted on nine counts of seconddegree murder for performing childbirth deliveries at home or at his personal office utilizing methods that were absolutely not in accordance with the medical practice at that time, thereby indirectly causing the death of nine children. In one instance, Doctor Klvana even went so far as to tell one of the parents to bury the dead baby in the backyard and not tell anyone about the death. He was convicted of seconddegree murder based on implied malice, on account of engaging in conduct that endangers the lives of others, and acting deliberately with conscious disregard for human life (Grunsven, 1997).

A country's health system is of paramount importance to its citizenry (especially in countries with compulsory health insurance) and accordingly should be protected from outside and inside threats, including from medical professionals that have demonstrated an inability to perform their sworn and sacred duties.

\subsection{General prevention of future negligent conduct}

Criminal repression has two effects on crime. The first is special prevention - by sending the offender to jail and/or in conjunction with other punitive sanctions, society prevents or at least deters the health care/offender from repeating the same or another crime again. The second is general prevention - by punishing and potentially sentencing the offender to jail, others at least theoretically will be deterred from committing acts that amount to criminal offences (Bavcon et. al., 2014). By criminally sanctioning the negligent doctor, society hopefully deters other doctors from making the same mistake or at least sends a message to other medical professionals encouraging them to be more careful and prudent in the future. ${ }^{11}$ Whether this argument is true depends on the questionable premise that the threat of possible criminal prosecution actually is a deterrent to a healthcare professional making errors (Marry, 2009). Criminal law prevention should not be used where it unlikely to actually deter and help to prevent the mischief (Ashworth \& Horder, 2013). Arguments pointed in chapters 3.1, 3.2. and 3.3. of this article can also be presented to contradict the argument of general prevention.

Nonetheless, we can argue, as in chapter 4.1. of this article, that in the most obvious cases of undisputed medical negligence or carelessness, where the inappropriate conduct has led to a serious deterioration of health or even death of a patient, the malfeasant doctor should be criminally prosecuted - either for a special offence of 
medical error or negligent treatment, or for common criminal offences of manslaughter, causing the death of another out of negligence, wounding or inflicting bodily harm, etc.

\subsection{Sanitation of a medical system gone wrong - the case of Japan}

When the criminal justice system completely ignores the medical profession and when the rules of the criminal justice system do not apply, arrogance can lead the doctors to consider themselves above the law, with potentially disastrous consequences for patients. This was nowhere as evident as it was in Japan before the year 1990. The creed of medieval Japan's feudal lords in ruling their subjects "Keep them ignorant and dependant" was often ironically applied to doctor's methods of managing patients (Leflar, 2009). Customary practices, for example, hid cancer diagnoses from patients, allowed for the withholding of information about prescription drugs, tolerated the refusal of doctors to give their patients access to their medical records, and sometimes conditioned provision of medical treatment on the patient's waiver of the right to sue or complain (Lafler, 2009). ${ }^{12}$ The state of medical chaos in Japan calmed down after some successful criminal prosecutions for an offence of professional negligence causing death or injury with prison sentence up to 5 years for the offender (Leflar \& Futoshi, 2005). A research by Leflar and Futoshi (2005) shows that there were only 21 medical accidents reported to Japanese Police in the year 1997, however in the year 2003 this number rose to 248. Authors of the research also report that even though the number of medical accidents have risen significantly, the status of medical treatment of patients in Japan has improved quite significantly. The Japanese experience therefore demonstrates that invoking the threat of criminal law sanctions can be an effective tool a state can use in order to prevent serious abuses by the medical profession.

\subsection{Privileged criminal offence with milder sentence}

Every day health care professionals are required to make complex and difficult decisions that will influence people's lives. Taking into account the known Latin phrase "To err is human" it becomes evident that the criminal law should show a fair amount of lenience and restraint in cases involving doctor error, especially since medical error occurs frequently; usually without malice; and, since there is significant stigma that will attach to doctors that are criminally convicted. Also, imposing criminal liability, except in the most egregious of cases, will surely have a chilling effect on persons deciding to enter the medical profession, and this can itself have adverse public policy consequences. As pointed out by a respected oncologist Zwitter (2012) "The doctor is increasingly alone and often bitter, torn between professionally optimal medicine, unrealistic policy requirements and overexpectations of the patients on the one hand, and among the practically feasible on the other." 
Considering the nature of the doctor's work, we can therefore argue that a special criminal offence of negligent medical treatment is an appropriate sanction for a doctor, when that sanction excludes a doctor's responsibility for a more serious crime committed out of negligence. In this regard, a special criminal offence for medical professionals should be considered as a privileged criminal offence. A privileged criminal offence is a construct of continental criminal law doctrine, which expresses a milder form of a criminal offence that differs from the fundamental one by certain aspects of execution, guilt elements of the perpetrator, and in a milder sanction.

The existence of Article 179 (Negligent medical treatment and healing activities) in the Slovenian Criminal Code effectively means that a negligent doctor, who causes the death of a patient, will not be responsible for causing death out of negligence after Article 118 of the Criminal Code, and if he causes serious bodily harm, the doctor will only be liable after Article 179, and not after Article 123 (Serious bodily harm). We can argue that this special offence after Article 179 of the Slovenian Criminal Code committed out of negligence (a doctor who causes the death of a patient with direct intent or dolus eventualis, will be liable for murder after Article 115 or Article 116 of the Slovenian Criminal Code) is a compromise between ignoring criminal repression in the medical field and the need to penalize obvious medical errors that result in a serious deterioration of health or even death of a patient that could have been avoided. Therefore, this would be a sensible legislative solution if this were a privileged criminal offence - meaning that the legislator would take into account the risk and the stress of the medical profession and propose a milder sentence for a negligent doctor who causes deterioration of health or death of a patient that should have been avoided.

Nonetheless, this is not the case in the Slovenian criminal legislation. If a nonmedical person causes the death of another as a result of negligence (e.g. worker at a construction site who should have secured a danger zone forgets to do it and because of that another worker dies), this person will be prosecuted in accordance with Article 118 (Causing the death of another out of negligence) and if convicted faces imprisonment from six months to five years. However, if a negligent doctor causes the death of another as a result of negligence, the doctor will be prosecuted after paragraph 3 of Article 179 and if convicted faces the prospect of imprisonment from one to eight years! This means that Article 179 of the Slovenian Criminal Code in fact defines a qualified offence - an offence with a higher sentence, and which differs from the fundamental one (Article 118) by certain aspects of execution and guilt elements of the perpetrator. The same applies when a negligent doctor causes serious bodily harm to a patient as a result of negligence. In accordance with paragraph 3 of Article 123 - Serious bodily harm (which is the fundamental injury offence), a non-medical person causing another person serious bodily harm as a result of negligence can be sentenced with imprisonment of up to two years. However, if this is a doctor, he or she will be liable after paragraph 1 of Article 179 with imprisonment of up to three years. This means that the Slovenian legislator 
does not put much trust in Slovenian doctors and other medical professionals and is sentencing them more severely with more extreme criminal repression than nonmedical persons for causing serious bodily harm or death of another as a result of negligence. The argument by the legislator in support of this dichotomous treatment is that the law must provide the highest legal security when it comes to medical profession (Korošec, 2016). However, this argument is quite dubious, since there are many other legal and non-legal options ${ }^{13}$ that the Slovenian government could have taken in order to provide better standards and security in the Slovenian health system. The other argument in support of doctor criminalisation is that the patient is in hopeless, ignorant position when confronted with a doctor (weak party status) and that an abuse of a doctor's trust demands stricter criminal repression. While this argument might have superficial appeal, in reality this approach demonstrates a high (misplaced and unfounded?) distrust in Slovenian doctors and only serves to promote resentment among doctors that is manifested in many ways, including beneficial expert testimony against colleagues at court - also known as guild association testimony.

Over-criminalising the work of medical professionals is hardly the best solution to the problems extant in the Slovenian health care system. It would be therefore sensible either to abrogate the special criminal offence defined in Article 179 from the Slovenian Criminal Code, or to modify this offence in to a privileged offence for medical professionals with a reduced sentence.

\section{Conclusion}

The criminal law's impact and effects on the medical profession are both profound and complicated. Questions concerning the patient's informed consent, understanding of the procedures being performed, euthanasia, manipulation of the person's genome, trading with body parts, and medical experiments on people are all very complex. Nonetheless, one of the most basic dilemmas the criminal law faces is whether negligent medical treatment, also known as medical malpractice or medical error, should be criminally prosecuted. We presented arguments against criminalisation of medical error, where the strongest arguments are uncertainty of exactly what the correct medical standards are, counterproductive criminalisation as seen by the practice of defensive medicine, using criminal law sanctions as a method of last resort, the arguments of justification and excuse, and of doctor's immunity. On the other hand, arguments favouring the criminalisation of medical error include obvious negligent treatment with serious consequences, the general prevention of future negligent conduct in medicine, the sanitation of a medical system gone wrong - as exemplified by the Japanese experience, and the argument of privileged criminal offence with milder sentence.

After considering all of these arguments, it is quite safe to say that doctors should not have a blanket exclusion from criminal repression merely because of their sometimes exalted status as medical providers. To the contrary, the criminal 
prosecution of the most negligent of doctors, who due to their irrational, carefree or careless behaviour cause serious deterioration of health or death of a patient can and should be criminally sanctioned. There is no absolute argument that criminal prosecution should be completely excluded. There are however, arguments that criminal prosecution of doctors should be an exception and not a rule. There are also strong arguments to be made that because of the inherently risky nature of medicine, there should be a privileged criminal offence for negligent doctors with lower sentence in comparison to the fundamental offences of causing death or serious bodily harm to another due to negligence. Despite this, the Slovenian legislator to date has not adapted such an approach. The Slovenian Criminal Code has a qualified offence for medical professionals with higher sentence in Article 179 of the Criminal Code, when death or serious deterioration of health of a patient is attributed to the negligence of a medical professional. Such a distrusting attitude toward Slovenian medical providers from a criminal law aspect is nothing to be proud of and will surely not contribute to let alone advance the quality of the Slovenian health system. In our judgment, it would be more sensible as a matter of public policy either to abolish the special offence defined in Article 179 from the Criminal Code, or to modify this offence into a privileged offence for medical professionals with reduced sentence.

\section{Statement}

I hereby declare that this manuscript is my original work, that is has not been published elsewhere and that it has not been submitted simultaneously for publication elsewhere.

\section{Notes}

${ }^{1}$ Germany and Austria - countries that the Slovenian legislator often looks after when writing new incriminations, are not familiar with the special offence of negligent treatment in medicine. However, the Croatian Criminal Code also has a special offence of negligent medical treatment in Article 181 (see also Turković, 2012).

${ }^{2}$ Criminal Code of the Republic of Slovenia (KZ-1) adopted in 2008, last amended in 2017, Slovenian Parliament

${ }^{3}$ In this article when we are discussing doctors, we also mean all other medical professionals who are responsible for treating a patient.

${ }^{4}$ This is however a very medical or technical definition which does not help the legal definition.

5 High Court, Queen's Bench Division (1957) Bolam v. Friern Hospital Management Committee, case number 2 All ER 118, United Kingdom.

${ }^{6}$ Criminal Code of the Republic of Austria (Strafgesetzbuch) adopted in 1974, last amended in 2017, Austrian Parliament.

${ }^{7}$ Helling v. Carey (1974) The Supreme Court of Washington, 83 Wn.2d 514, USA

8 High Court, Queen's Bench Division (1957) Bolam v. Friern Hospital Management Committee, case number 2 All ER 118, United Kingdom.

${ }^{9}$ Constitutional Court of Republic of Slovenia (2012) decision Up-689/11 of 24. 1. 2012

${ }^{10}$ People v. Klvana (1992) 11 Cal. App 4th 1679, 15 Cal. Rptr. 2d 512. Callif., Nos. B048085, B065578, Court of Appeal, Second District, Division 1, USA California. 
11 This is also a theory of tort law (Heller, 2017).

${ }^{12}$ See also the case of Aoto Hospital already described in chapter 3.2.

${ }^{13}$ Improve the overall standards in hospitals, reduce work overload of medical personnel, introduce risk simulation trainings, and improve educations standards etc. (see also Jere Jakulin, 2017).

\section{References}

Ashworth, A. \& Holder, J. (2013) Principles of Criminal Law, 7th ed. (Oxford: Oxford University Press).

Bavcon, L., Šelih, A., Korošec, D., Ambrož, M. \& Filipčič. K. (2014) Kazensko pravo, splošni del (Ljubljana: Uradni list Republike Slovenije).

Brenner, L., Brenner, A., Awerbuch, E. \& Horwits, D. (2012) Beyond the Standard of Care: A New Model to Judge Medical Negligence, Clinical Orthopaedics and Related research, 470(5), pp. 1357-1364, doi: 10.1007/s11999-012-2280-0.

Criminal Code of the Republic of Slovenia (KZ-1) adopted in 2008, last amended in 2017, Slovenian Parliament.

Dežman, Z. (2010) Zakon o pacientovih pravicah in njegov kazensko pravni vidik, In: Rijavec, V., Reberšek Gorišek, J., Flis, V., Planinšec, V. \& Kraljič, S. (eds.) Medicina in pravo, sodobne dileme II (Maribor: Faculty of Law of University of Maribor), pp. 375-388.

Dworkin, R. (1988) Law's Empire (Cambridge: Harvard University Press).

Flis, V. (1994) Medicinska napaka, In: Flis, V. \& Planinšec, V. (eds.) Medicina in pravo II, Odgovornost zdravnika, Medicinska napaka (Maribor: Slovensko zdravniško društvo v Mariboru in Pravniško društvo v Mariboru), pp. 47-67.

Flis, V. (2016) No Fault Compensation for Medical Injuries, Medicine, Law \& Society, 9(2), pp. 73-84, doi: 10.18690/24637955.9.2.73-84(2016)

Grunsven, P. (1997) Medical Malpractice or Criminal Mistake - An Analysis of Past and Current Criminal Prosecutions for Clinical Mistakes and Fatal Errors, DePaul Journal of Health Care Law, 2(1), pp. 1-54.

Halmich, M. (2016) Strafrechtsnovelle bringt Änderungenim Medizinstrafrecht, available at: https://www.halmich.at/strafrechtsnovelle-bringt-aenderungen-immedizinstrafrecht/ (December 5, 2017).

Heller Allan, T. (2017) An Overview of Medical Malpractice Law in the United States Including Legislative and the Health Care Industry's Responses to Increased Claims, Medicine, Law \& Society, 10(2), pp. 139-163, doi: 10.18690/2463-7955.10.2.139163.2017.

Helmer, O. \& Rescher, N. (1959) On the Epistemology of Inexact Sciences, Management Science, 6(1), pp. 25-52, doi: 10.1287/mnsc.6.1.25.

Jere Jakulin, V. (2017) Systems Methodology for Strategic Decision-making in Complex Healthcare Systems, Medicine, Law \& Society, 10(2), pp. 121-138, doi: 10.18690/2463-7955.10.2.121-138.2017.

Jescheck, H. H. \& Weigend, T. (1996) Lehrbuch des Strafrechts, Allgemeiner Teil (Berlin: Duncker \& Humblot).

Kennerly, M. (2017) Medicine Is Not An Exact Science (Countering A Defensive Medicine Myth), available at: https://www.litigationandtrial.com/2013/12/articles/attorney/exact-sciencedefensive-medicine-myth/ (December 7, 2017) 
King, L. S. (1952) Is Medicine an exact science? Philosophy of Science, 19, pp. 131-140, doi: $10.1086 / 287185$.

Kohn, L., Corrigan, J. \& Donaldson, M. (2000) To Err Is Human: Building a Safer Health System (Washington: National Academies Press).

Korošec, D. (2016) Medicinsko kazensko pravo, 2nd ed. (Ljubljana: GV Založba).

Korošec, D. (2016) Criminal Law Dillemas in Withholding and Withdrawal of Intensive Care, Medicine, Law \& Society, 9(1), pp. 21-39, doi: 10.18690/24637955.9.1.2139(2016).

Leflar, R. \& Iwata, F. (2005) Medical Error as Reportable Event, as Tort, as Crime: A Transpacific Comparison, Widener Law Review, 12, pp. 189-225.

Lefler, R. (2009) The Regulation of Medical Malpractice in Japan, Clinical Orthopaedics and Related Research, 467(2), pp. 443-449, doi: 10.1007/s11999-008-0602-z.

Matz, S. (1989) Der ärtzliche Kunstfehler und sein Beweis, In: Kaufman, A. (ed.) Moderne Medizin und Strafrecht (Heidelberg: CF Müller Juristischer Verlag).

Merry, A. (2009) How does the law recognize and deal with medical errors? Journal of the Royal Society of Medicine, 102(7), pp. 265-271, doi: 10.1258/jrsm.2009.09k029.

Miller, R., Sampson, N. \& Flynn, J. (2012) The prevalence of defensive orthopaedic imaging: a prospective practice audit in Pennsylvania, Journal of Bone and Joint Surgery, 94(3), doi: 10.2106/JBJS.K.00646.

Oyebode, F. (2013) Clinical Errors and Medical Negligence, Medical Principles and Practice, 22(4), pp. 323-333, doi: 10.1159/000346296.

Pandit, M. \& Pandit, S. (2009) Medical negligence: Criminal prosecution of medical professionals, importance of medical evidence: Some guidelines for medical practitioners, Indian Journal of Urology, 25(3), pp. 329-383, doi: 10.4103/09701591.56207.

Pandit, M. \& Pandit, S. (2009) Medical negligence: Coverage of the profession, duties, ethics, case law, and enlightened defence - A legal perspective, Indian Journal of Urology, 25(3), pp. 372-378, doi: 10.4103/0970-1591.56206.

Prosser, W. (1978) Law of Torts, $4^{\text {th }}$ ed. (Minnesota: West Publishing Company)

Roxin, C. (2003) Strafrecht, Allgemeiner Teil II, Besondere Erscheinungsformen der Straftat (München: Beck).

Ormerod, D. (2005) Smith \& Hogan Criminal Law, 11th ed. (New York: Oxford University Press).

Sonny Bal, B. (2009) An Introduction to Medical Malpractice in the United States, Clinical Orthopaedics and Related Research, 467(2), pp. 339-347, doi: 10.1007/s11999008-0636-2.

Turković, M. (2012) Nesavjesno liječenje, Ius Info, available at: http://www.iusinfo.com.hr/DailyContent/Topical.aspx?id=13137 (December 18, 2017)

Zwitter, M. (2012) Položaj zdravnika v sodobni družbi, In: Reberšek Gorišek, J. \& Ivanc, T. (ed.) Medicina in pravo, Odsev medicine in prava v sodobni družbi (Maribor: Faculty of Law of University of Maribor), pp. 63-69. 
